\title{
Genetic control of soybean earliness and yield through the Hayman methodology
}

André Ricardo Gomes Bezerra ${ }^{1, *}$, Tuneo Sediyama ${ }^{2}$, Cosme Damião Cruz ${ }^{3}$, Felipe Lopes da Silva ${ }^{2}$, Pedro Crescêncio de Souza Carneiro ${ }^{3}$, Guilherme de Sousa Paula ${ }^{1}$ and Waggner Gomes Palharini ${ }^{4}$

${ }^{1}$ Fundação MS Para Pesquisa e Difusão de Tecnologias Agropecuárias, Maracaju, MS, Brazil. ${ }^{2}$ Universidade Federal de Viçosa, Departamento de Fitotecnia, Viçosa, MG, Brazil. ${ }^{3}$ Universidade Federal de Viçosa, Departamento e Biologia Geral, Viçosa, MG, Brazil. ${ }^{4}$ Research and Development, Bayer Crop Science, Dourados, MS, Brazil. *Corresponding author, E-mail: andrebezerra@fundacaoms.org.br

\begin{abstract}
The understanding of the genetic control involved in characters of agronomic interest is of extreme importance to breeders aiming at planning procedures for breeding programs. Thus, the objective of this work was to study genetic aspects related to earliness and grain yield found in the initial generations of soybean, twice each year. The study evaluated six soybean parents (MSOY6101, RSF6563IPRO, TMG123RR, SYN9078RR, TMG801 and MSOY9144RR) and their $15 \mathrm{~F}_{1}$ 's in a greenhouse, during winter and summer. A second experiment conducted at Prof. Diogo Alves de Melo experimental field, located on the UFV campus, in Viçosa-MG, during the 2014/2015 agricultural year assessed parents and their segregating populations ( $\left.F_{2}\right)$. In all experiments, information were collected from individual plants. Results showed that both additive and dominance effects were important for the genetic control of soybean earliness and grain yield. Number of days to flowering and maturation and grain yield for the $F_{1}$ and $F_{2}$ generations, in winter and summer, is determined by dominant alleles. In regards to the studied characters, there was partial dominance mainly for the $F_{1}$ generation and overdominance for the $F_{2}$ generation. Parents MSOY6101 and RSF6563IPRO showed greater concentration of favorable alleles for flowering and maturation time reduction, and parents TMG123RR and SYN9078RR for grain yield. Parents TMG801 and MSOY9144RR gave the best contribution to cycle retardation for the $\mathrm{F}_{2}$ generation.
\end{abstract}

Key words: Glycine max, flowering days, maturation days, dominance average degree.

\section{INTRODUCTION}

In the largest Brazilian soybean - growing region, the Midwest, the main growers' demand is for early and productive cultivars that make second season cultivation possible. Therefore, the development of cultivars with earliness and production stability characteristics will certainly contribute to the progress of the Brazilian soybean growing culture.

Most characters of economic importance in different species, as in the case of soybean grain yield, are of the quantitative type, i.e., there are several genes involved in their genetic control. However, the environment effect is the great disturbing element in the study of quantitative characters, creating the need to accumulate information to get safe data for genetic breeding.

In regards to earliness, current literature describes ten genes that control soybean flowering and maturation: $E_{1} \mathrm{e}$ $E_{2}$ (Bernard 1971), $E_{3}$ (Buzzell 1971), $E_{4}$ (Buzzell and Voldeng 1980), $E_{5}$ (McBlain and Bernard 1987), $E_{6}$ (Bonato and Vello 1999a), $E_{7}$ (Cober and Voldeng 2001), $E_{8}$ (Cober et al., 2010), $E_{9}$ (Kong et al., 2014) and $J$ (Ray et al., 1995). Dominant alleles for $E_{6}, E_{9}$ and $J$ promote early flowering, while the dominant alleles for the other loci delay flowering and maturation (Zhao et al., 2016). E6 and $J$ were identified in progenies originated from the crossing between a standard cultivar and another with late flowering and long juvenile period, which cause flowering delay even during short days (Bonato and Vello 1999a; Cober et al., 2010). Bonato and Vello (1999a) found that $E_{6}$ is the allele that determines flowering and maturation earliness in the Paraná cultivar and e6 determines late flowering and maturation in Paranagoiana and SS-1. In another work, Bonato and Vello (1999b) observed that the key genetic variation compound for flowering time determination is additive and the alleles that restrict earlier flowering show partial dominance.

There is also the registration of three QTL's that act on the genetic control of soybean flowering time, FT1, FT2 e FT3 (Yamanaka et al., 2001). These QTL`s correspond to loci $E_{1}, E_{2}$ and $E_{3}$, respectively, based on their positions in the genetic map and allelism tests (Tsubokura et al., 2014).

Different genetic mechanisms are related to soybean photoperiodic insensitivity. At least three multi-loci genotypes constituted by several allelic combinations of $E_{1}, E_{3}$ and $E_{4}$ confer photoperiodic insensitivity to soybean cultivars, but lead to different responses to the photoperiod during the post-flowering reproductive and vegetative development. A control system is attributed to the double-recessive genotype, which codifies the phytochrome (PHYA), protein GmPHYA3 and GmPHYA2, respectively. Genes $E_{3}$ and $E_{4}$ are the main controllers involved not only in pre-flowering but also in post-flowering responses (Xu et al., 2013).

Despite the importance of knowing the mechanisms involved in the control of number of days to maturation and grain yield characteristics, only a few studies, until now, were carried out under Brazilian conditions. In the last years, new genetic sources have been introduced to the Brazilian germplasm, mainly those originating from Argentina, demanding the development of new studies. Tsubokuara et al. (2014) suggest that there are still unidentified genes 
that act on genetic control of flowering in soybean. In this context, the objective of the present work was to study genetic aspects related to grain earliness and yield in soybean initial generations, during two periods of the year.

\section{MATERIALS AND METHODS}

\section{Parents and Fis evaluation}

Experiments occurred in two periods, being the first sown in May 2014, characterizing the winter period (or intercrop period) and the second in November 2015, characterizing the summer period. Six parents and their hybrids (21 treatments) were evaluated in a greenhouse at Universidade Federal de Viçosa Plant Science Department, located on the University Campus,Viçosa, Minas Gerais, Brasil. Photoperiod from sowing to the flowering of the earliest parent was practically constant in winter, with variation from 10 hours and 54 minutes to 10 hours and 56 minutes and of 12 hours and 55 minutes to 13 hours and 13 minutes in summer.

Selected parents are commercial cultivars, contrasting and from the relative maturity group (GMR), which includes the Brazilian soybean cultivated area (Table 1), with differences in relation to number of days to maturation if cultivated under the same conditions (Figure 1).

Table 1. List of parents of crossed soybean under a complete diallel scheme for the study of the genetic control of grain earliness and yield, in Viçosa, MG, Brazil.

\begin{tabular}{lcccl}
\hline \multicolumn{1}{c}{ Parent } & Type of growth. & RMG $^{1}$ & NGP $^{2}$ & Leaf \\
\hline MSOY6101 (P1) & Undetermined & 6.1 & 2 to 3 & Pointed oval \\
RSF6563IPRO (P2) & Undetermined & 6.3 & 2 to 3 & Pointed oval \\
TMG123RR (P3) & Determined & 7.4 & 3 to 4 & Lanceolate \\
SYN9078RR (P4) & Undetermined & 7.9 & 2 to 3 & Pointed oval \\
TMG801 (P5) & Determined & 8.2 & 2 to 3 & Pointed oval \\
MSOY9144RR (P6) & Determined & 9.1 & 2 to 3 & Pointed oval
\end{tabular}

${ }^{1} \mathrm{RMG}=$ Relative maturity group; and ${ }^{2} \mathrm{NGP}=$ Average number of grains per pod variation.

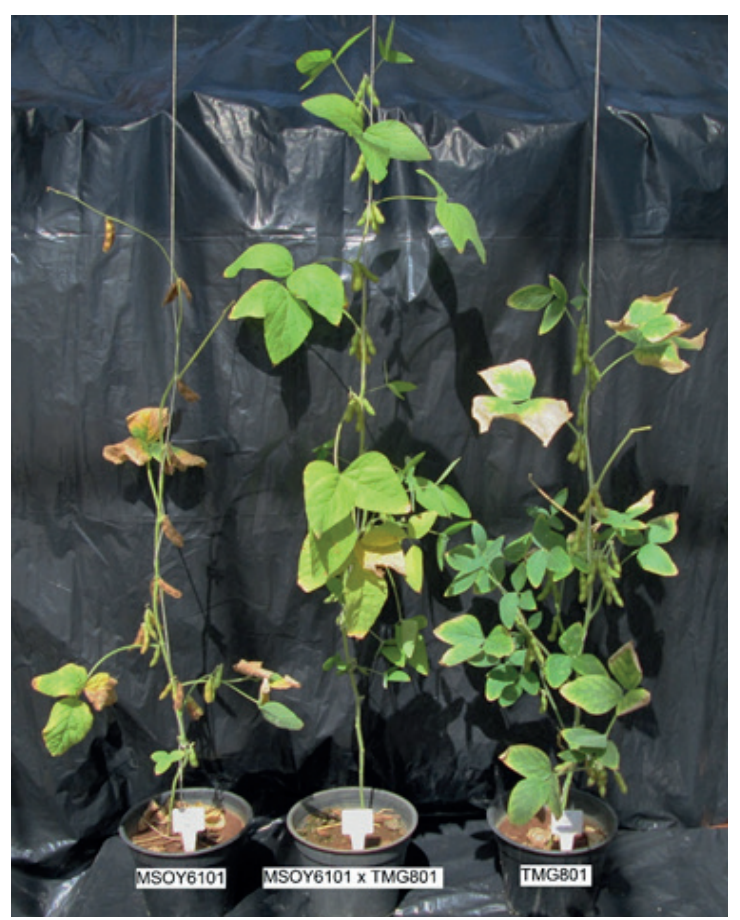

Figure 1. Representation of different cycles between divergent parents for growth type and Relative Maturity Groups (RMG). MSOY6101, undetermined and RMG = 6.1; TMG801, determined and RMG = 8.2; and, $\mathrm{F}_{1}$, undetermined, with intermediate maturation to their parents. 
The study adopted a randomized block design with six replications. Each parcel included a $3 \mathrm{dm}^{-3}$ pot with one plant. The substrate used was a mix of soil and cattle manure in the 3:1 proportion. Substrate fertility and $\mathrm{pH}$ corrections took into consideration the demand for pot cultivation (Novais et al., 1991) and the other treatments were those recommended for the crop. Seeds were treated with fungicide and inoculated with Bradyrbizobium japonicum $\left(5.0 \times 10^{9}\right.$ viable cells per $\left.\mathrm{mL}\right)$, in the dose of $100 \mathrm{ml}$ for $50 \mathrm{~kg}$ of seeds.

Number of days to flowering, days to maturation and grain yield ( $\mathrm{g} / \mathrm{plant}$ ) were calculated. Number of days between emergence and flowering and between emergence and plant physiological maturation followed the scale proposed by Fehr and Caviness (1977).

\section{Parents' evaluation and $\mathrm{F}_{2}$}

The $15 \mathrm{~F}_{2}$ populations obtained from the self-fecundation of $\mathrm{F}_{\mathrm{I}}$ 's described above were evaluated in the field. The experiment was conducted at Prof. Diogo Alves de Melo Experimental Field, located at the University Campus, in Viçosa, Minas Gerais, during the 2014/2015 agricultural year. Located in an area of latitude south at $20^{\circ}$ 46' and longitude west at $42^{\circ} 52^{\prime}$. The climate in the region is, according to the Köppen classification of type Cwa, i.e., humid subtropical, with dry winters. Average rainfall is less than $60 \mathrm{~mm}$ in at least one month during this season. The summer is hot and the average temperature for the hottest month is over $22{ }^{\circ} \mathrm{C}$ (Alvares et al., 2013). Photoperiod, from sowing to the beginning of the earliest parent flowering, varied from $12 \mathrm{~h} 52 \mathrm{~min}$ to $13 \mathrm{~h} 13 \mathrm{~min}$.

Treatments included 15 segregating populations and their six parents (Table 1). The parent MSOY9144RR was used as the experiment's lateral edge. Soil was fertilized with $200 \mathrm{~kg} \mathrm{ha}^{-1}$ with a formula containing $4 \%$ of N, 14\% of $\mathrm{P}_{2} \mathrm{O}_{5}$ and $8 \%$ of $\mathrm{K}_{2} \mathrm{O}$.

Sowing occurred in November 2014, using randomized blocks with three replications. Populations and parents were evaluated in parcels with three 6 meter - long lines, spaced at $0.7 \mathrm{~m}$. Each parcel included 140 seeds with seeding density of approximately 8 seeds per linear meter. All cultural treatment followed the technical recommendations for the culture. The characters assessed in this study were evaluated in regards to days to flowering, days to maturation and grain yield ( $\mathrm{g} / \mathrm{plant})$.

\section{Statistical analyses}

Data were submitted to an individual analysis of variance and dialectical analysis by the method proposed by Hayman (1954) and adaptation to $\mathrm{F}_{2}$ proposed by Jinks (1956). The sufficiency test of the additive-dominant model was based on the linear regression analysis of the covariance between parents and the $r$-th line $\left(\hat{\mathrm{W}}_{\mathrm{i}}\right)$ over the variance between the lines $\left(\hat{V}_{i}\right)$, in which the regression coefficient $(b)$ is equaled to the unit (Ho:bi=1) and, in case of an agreement, the hypothesis was validated. In case of lack of agreement, a second test can be applied after the weighing of the values of $\hat{\mathrm{W}}_{\mathrm{i}}$ and $\hat{\mathrm{V}}_{\mathrm{i}}$, with axels rotation at $45^{\circ}$, followed by a new regression coefficient (Ho:b'o=0).

The following genetic compounds were estimated: $\hat{\mathrm{D}}$, variance compound due to additive effects; $\hat{\mathrm{H}}_{1}$, variance compound due to non-additive genic effects; $\hat{\mathrm{H}} 2$, genetic compound of the non-genic additive, corrected for genic distribution, which is an indicator of the asymmetry of the genes with positive and negative effects; $\hat{\mathrm{h}}^{2}$, quadratic compound determined by the mean difference between hybrids and parents; F, genetic compound of the covariance between additive and non-additive genic effects, which is an indication of the relative frequencies of dominant and recessive between parents; $\hat{\mathrm{E}}$, environmental variance compound.

The following genetic and non-genetic parameters were estimated: $\hat{\mathrm{H}}_{2} /\left(4 \hat{\mathrm{H}}_{1}\right)=$ alleles distribution between parents symmetry; $\left(\hat{\mathrm{H}}_{1} / \hat{\mathrm{D}}\right)^{0,5}=$ dominance average degree; $\hat{\mathrm{W}}_{\mathrm{i}}+\hat{\mathrm{V}}_{\mathrm{i}}=$ dominant and recessive alleles concentration in parents; $\left(4 \hat{\mathrm{D}} / \hat{\mathrm{H}}_{1}\right)^{0,5}+\hat{\mathrm{F}} /\left(4 \hat{\mathrm{D}} / \hat{\mathrm{H}}_{1}\right)^{0,5}-\hat{\mathrm{F}}=$ average relation of number of dominant and recessive genes; $\left(\hat{\mathrm{Y}}_{\mathrm{R}}, \hat{\mathrm{Y}}_{\mathrm{D}}\right)=$ selection theoretical limits; $r\left(\hat{\mathrm{W}}_{\mathrm{i}}+\hat{\mathrm{V}}_{\mathrm{i}}, \mathrm{Y}_{\mathrm{ii}}\right)=$ relationship between the gene effect and its dominance relation.; $\hat{\mathrm{h}}^{2} / \hat{\mathrm{H}}_{2}=$ number of genes with dominance; $b=$ covariance regression coefficient estimate over the dialectical table variances; $h_{R}{ }^{2}=$ determination restricted-sense coefficients; and $\mathrm{h}_{\mathrm{A}}^{2}=$ determination of broad-sense coefficients. All statistical procedures were carried out with help of the Genes program (Cruz 2013).

\section{RESULTS AND DISCUSSION}

\section{Fis assessment results}

The sufficiency of the additive-dominant model can be attested by the results of the two tests, based on the regression analysis of $\hat{\mathrm{W}}_{\mathrm{i}}$ in $\hat{\mathrm{V}}_{\mathrm{i}}$. The regression coefficients for all characters varied from 0.09 to 1.01 (Table 2). Exceptionally, in one of the tests, the days to maturation characters, in the winter, and grain yield per plant, in the summer, differed by $b_{\mathrm{I}}=1$. 
Table 2. Sufficiency test of the additive-dominant model based on the linear regression analysis of $\hat{\mathrm{W}}_{\mathrm{I}}$ in $\hat{\mathrm{V}}_{\mathrm{i}}$ for days to flowering, days to maturation and drain yield per plant characters, assessed in two periods of the year, in a diallelic cross of six soybean parents and their F1's, according to the methodology proposed by Hayman (1954).

\begin{tabular}{|c|c|c|c|c|}
\hline \multirow{2}{*}{ Character } & \multirow{2}{*}{ Period } & \multicolumn{3}{|c|}{ Regression $\left(\widehat{W}_{i}=\hat{a}+\widehat{b}_{i}\right)$} \\
\hline & & $\widehat{\mathrm{b}} \pm$ variance & $\mathrm{t}\left(\mathrm{H}_{0}: \mathrm{b}_{1}=1\right)$ & $\mathrm{F}=\mathrm{t}^{2}\left(\mathrm{H}_{0}: \mathrm{b}^{\prime}{ }_{0}=0\right)^{1}$ \\
\hline \multirow{2}{*}{ Days to flowering } & Winter & $0.8317 \pm 0.2882$ & $-0.3135^{\mathrm{ns}}$ & $0.6188^{\mathrm{ns}}$ \\
\hline & Summer & $1.0054 \pm 0.0096$ & $0.0553^{\mathrm{ns}}$ & $0.0636^{\mathrm{ns}}$ \\
\hline \multirow{2}{*}{ Days to maturation } & Winter & $0.0980 \pm 0.0944$ & $-2.9361^{*}$ & $0.9951^{\mathrm{ns}}$ \\
\hline & Summer & $0.9619 \pm 0.0186$ & $-0.2784^{\mathrm{ns}}$ & $0.0001^{\mathrm{ns}}$ \\
\hline \multirow{2}{*}{ Yield (g/plant) } & Winter & $0.4783 \pm 0.2133$ & $-1.1296^{\mathrm{ns}}$ & $-0.0887^{\mathrm{ns}}$ \\
\hline & Summer & $0.5336 \pm 0.0153$ & $-3.7701^{*}$ & $6.9885^{\mathrm{ns}}$ \\
\hline
\end{tabular}

${ }^{1}$ Test $\mathrm{F}$, with average values of $\hat{\mathrm{W}}_{\mathrm{I}}$ and $\hat{\mathrm{V}}_{\mathrm{i}}$, weighed with axes rotation at $45^{\circ}$. ${ }^{\text {ns }}$ non-significant; *significant at $5 \%$ of probability, respectively, by the $\mathrm{F}$ test and by the $t$ test.

However, after the weighing process through axels rotation at $45^{\circ}$, they showed no difference by bo $=0$. Thus, results suggest the presence of epistasis in these two cases, mainly for grain yield where the presence of epistatic interactions was reported by other works (Barona et al., 2009, 2012; Yang et al., 2013).

Table 3 shows the genetic and environmental compounds estimated for the three characters studied. Compound significance of $\hat{D}$ compound, which is associated with the additive effects and its superiority in relation to the dominance effects compound for all characters in the periods assessed, suggests that the additive effects were more important for the characters' genetic control.

Table 3. Genetic and environmental estimates ( \pm Standard Deviation) for days to flowering, days to maturation and grain yield per plant characters obtained through the methodology proposed by Hayman (1954), for six soybean parents crossed in a complete diallel scheme and assessed with the $F_{1}$ 's.

Character

\begin{tabular}{ccccccc} 
Compound & \multicolumn{2}{c}{ Days to flowering } & \multicolumn{2}{c}{ Days to maturation } & \multicolumn{2}{c}{ Yield (g/plant) } \\
\cline { 2 - 7 } & Winter & Summer & Winter & Summer & Winter & Summer \\
\hline$\widehat{\mathrm{D}}$ & $14.06 \pm 2.56^{*}$ & $64.29 \pm 2.95^{*}$ & $1.13 \pm 1.37$ & $70.97 \pm 5.66^{*}$ & $4.19 \pm 1.51^{*}$ & $3.10 \pm 2.03$ \\
$\widehat{\mathrm{H}}_{1}$ & $10.20 \pm 6.50$ & $12.94 \pm 7.49$ & $8.49 \pm 3.49^{*}$ & $23.63 \pm 14.37$ & $1.50 \pm 3.82$ & $13.78 \pm 5.16^{*}$ \\
$\widehat{\mathrm{H}}_{2}$ & $9.20 \pm 5.81$ & $12.43 \pm 1.85$ & $5.93 \pm 3.12$ & $18.73 \pm 12.84$ & $1.84 \pm 3.41$ & $18.14 \pm 4.61^{*}$ \\
$\widehat{\mathrm{h}}^{2}$ & $-1.25 \pm 3.91$ & $1.45 \pm 4.51$ & $4.54 \pm 2.09^{*}$ & $9.25 \pm 8.64$ & $5.04 \pm 2.29^{*}$ & $41.63 \pm 3.10^{*}$ \\
$\overline{\mathrm{F}}$ & $6.03 \pm 6.26$ & $15.29 \pm 7.22^{*}$ & $0.304 \pm 3.36$ & $49.80 \pm 13.83^{*}$ & $1.54 \pm 3.68$ & $-3.91 \pm 4.96$ \\
$\widehat{\mathrm{D}}-\widehat{\mathrm{H}}_{1}$ & $3.86 \pm 5.71$ & $51.34 \pm 6.58^{*}$ & $-7.36 \pm 3.06^{*}$ & $47.34 \pm 12.62^{*}$ & $2.69 \pm 3.36$ & $-10.68 \pm 4.53^{\circ}$ \\
$\varepsilon$ & $2.97 \pm 0.968^{*}$ & $5.42 \pm 1.17^{*}$ & $0.728 \pm 0.519$ & $7.68 \pm 12.14^{*}$ & $1.76 \pm 0.569^{*}$ & $5.84 \pm 0.768^{*}$
\end{tabular}

$\hat{\mathrm{D}}=$ variance compound due to additive effects; $\hat{\mathrm{H}}_{1}=$ variance compound due to non-additive genic effects; $\hat{\mathrm{H}}_{2}=$ genetic variance compound for the non-additive genic effects corrected by the genic distribution; $\hat{\mathrm{h}}^{2}$, quadratic compound determined by the mean difference between hybrids and parents; $\mathrm{F}=$ covariance genetic compound between additive and non-additive genic effects; $\hat{D}-\hat{H}_{1}=$ compound that expresses the difference between additive and dominant genic effects; , environmental variance compound. 1 /Values of $\mathrm{t}$ obtained by the division of the effect estimate by its respective standard deviation (Singh and Chaudhary 1979$)$. ns $=$ non-significant. ${ }^{*}=$ significant (values over 1.96) at $5 \%$ of probability. 
Number of days to maturation in the winter and grain yield in the summer should be excepted, just the two cases in which one of the sufficiency tests of the additive-dominant model showed significance and the dominance effects $\left(\hat{\mathrm{H}}_{1}, \hat{\mathrm{H}}_{2} \mathrm{e} \hat{\mathrm{h}}^{2}\right)$ were more important. Toledo and Kiihl (1982), studying population derives from the D72-7842 $\mathrm{x}$ Santa Rosa cross, under short-days conditions (11 hours and 10 minutes to 12 hours and 30 minutes) during winter, verified that the additive and dominance effects were important for the number of days to soybean flowering.

The difference between the $\hat{\mathrm{D}}-\hat{\mathrm{H}}_{1}$ estimates also provides information on the genic effect on the character. When the estimate is negative, the dominance genic effects predominate; however, positive estimates reveal the presence of additive genetic effects.

As shown in Table 3, the $\mathrm{F}$ values, significant and positive for days to flowering, days to maturation in the summer, indicate that the dominant alleles were more frequent than the recessive in the set of parents studied. The average relation for number of dominant and recessive genes $\left(\mathrm{K}_{\mathrm{D}} / \mathrm{K}_{\mathrm{R}}\right)$ varied from 1.10 to 4.10 (Table 4). Dominant alleles of loci $E 1$ and $E 5$, under long-day conditions, are responsible for the late cycle and the recessive determine early maturation. Under short-day conditions, the response is inverted (Hartwig and Kiihl 1979). However, this study showed that under the longer-day condition (summer), the number of days until maturation and flowering were smaller for all parents in the diallel (Tabela 6). Except for parent 6 that have a gene that gives it a long juvenile period.

Table 4. Estimates for the genetic and non-genetic parameters for the days to flowering, days to maturation and grain yield per plant, obtained through the Hayman methodology (1954), for six soybean parent crossed under the complete diallel scheme and assessed with their F's.

Character

\begin{tabular}{ccccccc}
\cline { 2 - 6 } Parameter & \multicolumn{2}{c}{ Days to flowering } & \multicolumn{2}{c}{ Days to maturation } & \multicolumn{2}{c}{ Yield } \\
\cline { 2 - 7 } & Winter & Summer & Winter & Summer & Winter & Summer \\
\hline$\left(\widehat{\mathrm{H}}_{1} / \widehat{\mathrm{D}}\right)^{0.5}$ & 0.8518 & 0.4487 & 2.7413 & 0.5771 & 0.5986 & 2.1085 \\
$\widehat{\mathrm{H}}_{2} / 4 \widehat{\mathrm{H}}_{1}$ & 0.2255 & 0.2402 & 0.1746 & 0.1982 & 0.3056 & 0.3290 \\
$\mathrm{~K}_{\mathrm{D}} / \mathrm{K}_{\mathrm{R}}$ & 1.6732 & 1.7212 & 1.1033 & 4.1023 & 1.8881 & 0.5395 \\
$\mathrm{~h}^{2} / \widehat{\mathrm{H}}_{2}$ & -0.1363 & 0.1165 & 0.7663 & 0.4938 & 2.7439 & 2.2950 \\
$\mathrm{~h}_{\mathrm{R}}^{2}$ & 0.4613 & 0.7437 & 0.4337 & 0.5132 & 0.3433 & 0.1135 \\
$\mathrm{~h}_{\mathrm{A}}^{2}$ & 0.6965 & 0.8371 & 0.8134 & 0.6976 & 0.4794 & 0.5009
\end{tabular}

$\left(\hat{\mathrm{H}}_{1} / \hat{\mathrm{D}}\right)^{0,5}=$ average degree of dominance; $\hat{\mathrm{H}}_{2} /\left(4 \hat{\mathrm{H}}_{1}\right)=$ alleles distribution among parents (symmetry); $\mathrm{K}_{\mathrm{D}} / \mathrm{K}_{\mathrm{R}}=$ average relation for dominant and recessive genes; $\hat{h}_{2} / \hat{H}_{2}=$ number of genes with dominance; $h^{2}=$ restricted -sense determination coefficients; and $h_{A}^{2}=$ broad-sense determination coefficients.

Dominance average degree estimates $\left(\hat{\mathrm{H}}_{1} / \hat{\mathrm{D}}\right)^{0,5}$ for days to flowering, days to maturation in summer for the two periods studied, days to maturation in summer and grain yield in winter show partial dominance between alleles that act on genic control (Table 4). This result can be corroborated through a graphic analysis in cases where the regression line of $\hat{\mathrm{W}}_{\mathrm{i}}$ in $\hat{\mathrm{V}}_{\mathrm{i}}$ intercepts on the axis of the ordinates above the origin point (Figure 2).

There was overdominance for number of days to maturation in winter and grain yield in summer. Similar results were found by Bonato and Vello (1999a) for number of days to maturation, in the diallelic analysis between Paraná cultivars and their natural variations, Paranagoiana, SS-1 and Pirapó 78, under the photoperiod of 13 hours and 31 minutes to 14 hours and 23 minutes.

Alleles distribution among parents expressed by the ratio $\hat{\mathrm{H}}_{2} /\left(4 \hat{\mathrm{H}}_{1}\right)$ were below 0.25 for days to flowering and days to maturation (Table 4). Although, in the case of days to flowering, the values 0.2255 and 0,2402 for winter and summer, respectively, show a symmetric distribution of favorable or unfavorable alleles among the parents. On the other hand, the values observed for number of days to maturation, 0.1746 and 0.1982 for winter and summer, respectively, indicate an asymmetric distribution of alleles among the parents.

The same result is also evidenced by the estimate of the dominant/recessive alleles values relation $\left(\mathrm{K}_{\mathrm{D}} / \mathrm{K}_{\mathrm{R}}\right)$, in which there was predominance of recessive alleles only for grain yield, expressed by the ratio 0.5395 (Table 4).For the other characters there was a predominance of dominant alleles in relation to number of days to maturation in summer (4.10). 

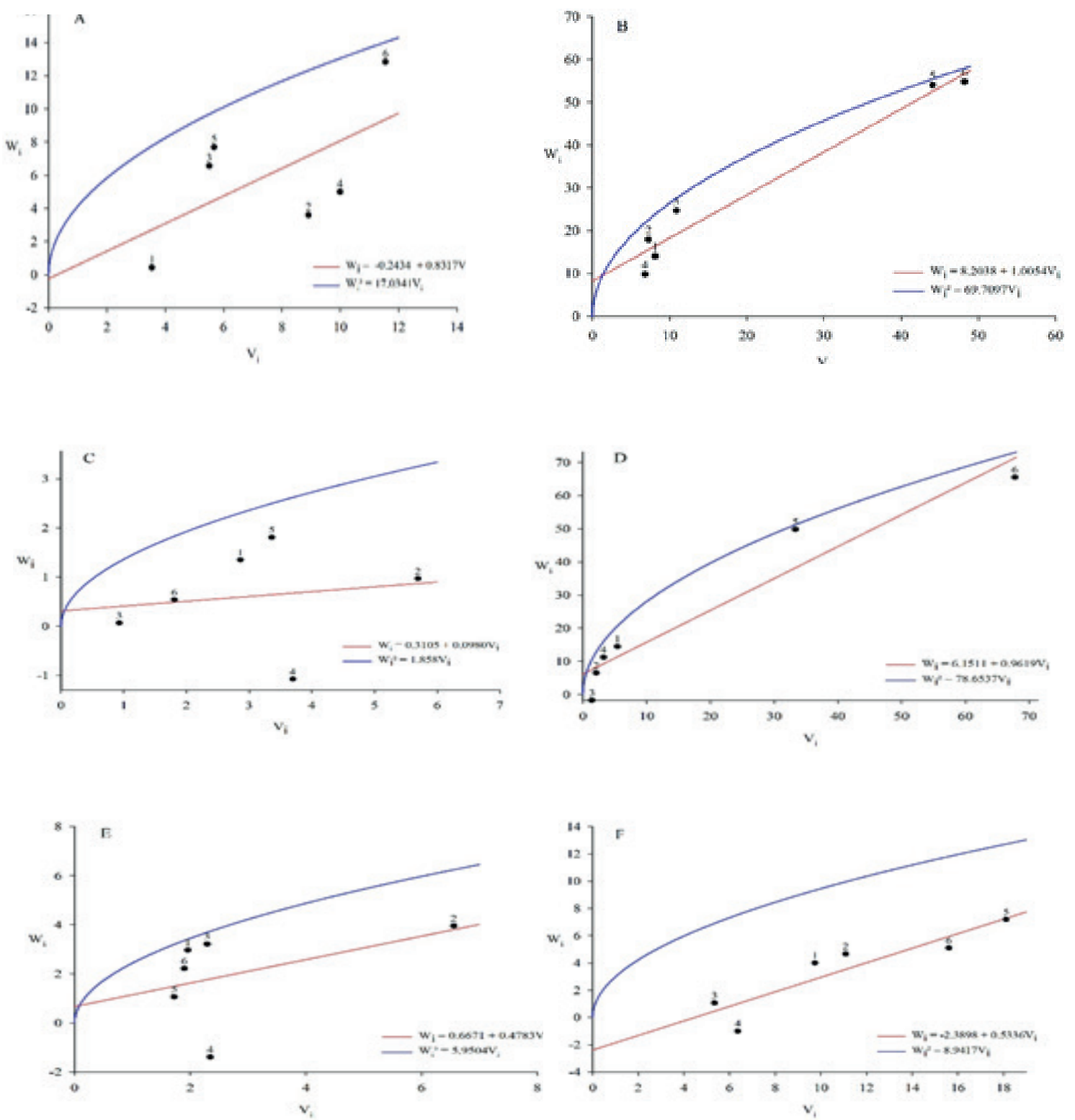

1- MSOY6101
2- RSF6563IPRO
3- TMG123RR

4- SYN9078RR

5- TMG801

6- MSOY9144RR

Figure 2. Regressions of $\hat{W}_{i}$ in $\hat{V}_{i}$ de for number of days to flowering $(A, B)$, number of days to maturation $(C, D)$, and grain productivity (E, F), evaluated in winter and summer, in diallel scheme with their F1's, in Viçosa, MG, Brazil, 2016.

Estimates for number of genes or genic blocks with dominance $\left(\hat{h}^{2} / \hat{H}_{2}\right)$ indicate the existence of at least one gene or genic block acting on the genetic control of the days to flowering and days to maturation characters and three on grain yield. However, it is important to emphasize that this estimator underestimates the number of genes with little or no dominance (Cruz et al., 2012).

Broad-sense determination coefficients $\left(h_{A}^{2}\right)$ for days to flowering $(0.6965$ and 0.8371 in winter and summer, respectively), for days to maturation (0.8134 and 0.6976 in winter and summer, respectively) and for grain yield (0.4794 and 0.5009 in winter and summer, respectively) and the restricted-sense determination coefficients $\left(\hat{\mathrm{h}}^{2}\right)$ for days to flowering ( 0.4613 and 0.7437 in winter and summer, respectively), days to maturation ( 0.4337 and 0.5132 for winter and summer, respectively) and grain yield ( 0.3433 and 0.1135 for winter ) show that the additive effects are predominantly involved in the genetic control of these characters (Table 4).

The correlation $r\left(\hat{\mathrm{W}}_{\mathrm{i}}+\hat{\mathrm{V}}_{\mathrm{i}}, \hat{Y}_{\mathrm{ii}}\right)$ indicates that the genes that act on the character are recessive or dominant. Table 5 shows that, for number of days to flowering, this correlation was null in the winter (-0.0992) and positive of high magnitude (0.9566). 
Table 5. Estimates for the correlations between the parents' mean values $\left(\hat{Y}_{i i}\right)$ and the covariance sum, between the parent's means and mean for the r-th line $\left(\hat{\mathrm{W}}_{\mathrm{i}}+\hat{\mathrm{V}}_{\mathrm{i}}\right)$, values expected for the coordinates $\left(\hat{\mathrm{W}}_{\mathrm{i}} \mathrm{R} ; \hat{\mathrm{V}}_{\mathrm{R}}\right) \mathrm{e}\left(\hat{\mathrm{W}}_{\mathrm{D}} ; \hat{\mathrm{V}}_{\mathrm{D}}\right)$ and the value predicted for the parent with maximum concentration of dominant alleles $\left(\hat{Y}_{\mathrm{iR}} ; \hat{\mathrm{Y}}_{\mathrm{iD}}\right)$, for six soybean parents, assessed with their F1's in a diallelic scheme, in winter and summer.

\begin{tabular}{|c|c|c|c|c|c|c|}
\hline \multirow[b]{2}{*}{ Character } & & \multicolumn{5}{|c|}{ Genetic parameters } \\
\hline & & $r\left(\widehat{W}_{1}+\widehat{V}_{1}, \bar{Y}_{n}\right)$ & $\left(\widehat{W}_{R} ; \hat{V}_{R}\right)$ & $\left(\widehat{W}_{D} ; \hat{V}_{D}\right)$ & $\begin{array}{l}\text { Prediction } \\
\text { equation }\end{array}$ & $\begin{array}{l}\text { Limit } \\
\left(\bar{Y}_{R} ; \bar{Y}_{D}\right)\end{array}$ \\
\hline & I & -0.0992 & $\begin{array}{l}(20.7222 ; \\
25.2088)\end{array}$ & $\begin{array}{l}(-0.2406 ; \\
0.0034)\end{array}$ & $\begin{array}{c}Y_{\mathrm{ii}}=57.996802- \\
0.062505\left(\mathrm{~W}_{\mathrm{i}}+\mathrm{V}_{\mathrm{i}}\right)\end{array}$ & $\begin{array}{l}(55.1259 ; \\
58.0116)\end{array}$ \\
\hline DF & $\mathrm{V}$ & 0.9566 & $\begin{array}{l}\text { (59.8246: } \\
51.3412)\end{array}$ & $\begin{array}{l}(9.5076: \\
1.2967)\end{array}$ & $\begin{array}{l}\mathrm{Y}_{\sqcup}=36.674279+ \\
0.201647\left(\mathrm{~W}_{\mathrm{i}}+\mathrm{V}_{\mathrm{i}}\right)\end{array}$ & $\begin{array}{l}59.0905: \\
38.8529)\end{array}$ \\
\hline & I & 0.7129 & $\begin{array}{l}\text { (18.6423: } \\
187.0459)\end{array}$ & $\begin{array}{l}(0.3158: \\
0.0537)\end{array}$ & $\begin{array}{c}\mathrm{Y}_{\mathrm{H}}=117.494421+ \\
0.46829\left(\mathrm{~W}_{\mathrm{i}}+\mathrm{V}_{\mathrm{i}}\right)\end{array}$ & $\begin{array}{l}\text { (213.8161: } \\
117.6675)\end{array}$ \\
\hline DNDI & $\mathrm{V}$ & 0.8763 & $\begin{array}{l}(75.0621 \\
71.6346)\end{array}$ & $\begin{array}{l}(6.7002, \\
0.5708)\end{array}$ & $\begin{array}{l}\mathrm{Y}_{\mathrm{ii}}=104.112215+ \\
0.145942\left(\mathrm{~W}_{1}+\mathrm{V}_{\mathrm{L}}\right)\end{array}$ & $\begin{array}{l}(125.5215 \\
105.1734)\end{array}$ \\
\hline Prod & I & -0.5645 & $\begin{array}{l}\text { (11.7323: } \\
\text { 23.1324) }\end{array}$ & $\begin{array}{l}(0.7073 \\
0.0841)\end{array}$ & $\begin{array}{c}\mathrm{Y}_{\mathrm{i}}=11.299922- \\
0.425135\left(\mathrm{~W}_{\mathrm{i}}+\mathrm{V}_{\mathrm{i}}\right)\end{array}$ & $\begin{array}{l}(-3.5223: \\
10.9635)\end{array}$ \\
\hline & $\mathrm{V}$ & -0.5747 & $\begin{array}{l}(18.8779 ; \\
39.8558)\end{array}$ & $\begin{array}{l}(-2.1212, \\
0.5032)\end{array}$ & $\begin{array}{c}Y_{\mathrm{i}}=22.874422- \\
0.219448\left(\mathrm{WW}_{\mathrm{i}}+\mathrm{V}_{1}\right)\end{array}$ & $\begin{array}{l}(9.9854 ; \\
23.2295)\end{array}$ \\
\hline
\end{tabular}

$\mathrm{DF}=$ days to flowering; $\mathrm{DM}=$ days to maturation; Prod = yield $(\mathrm{g} / \mathrm{plant}) ; \mathrm{W}=$ winter; $\mathrm{S}=$ summer.

Therefore, dominant alleles contribute to days to flowering time reduction and parent MSOY6101 showed greatest concentration of dominant alleles in the winter. As Figure 2A shows, parent MSOY6101 is located nearer the inferior regression line of $\hat{W}_{\mathrm{I}}$ in $\hat{\mathrm{V}}_{\mathrm{i}}$, and parent MSOY9144RR, with greater concentration of recessive alleles, is located in the opposed extremity. The other parents take an intermediate position, showing that they presented bi-directional dominance deviations, i.e., alleles that contribute to the reduction of flowering time and alleles that prolong the vegetative period

During the summer, parents MSOY6101, RSF6563IPRO, TMG123RR and SYN9078RR showed greater concentration of dominant alleles and parents TMG801 and MSOY9144RR showed greater concentration of recessive alleles (Figure 2B). The same conclusions can be reached by the sum of $\hat{\mathrm{W}}_{\mathrm{i}}+\hat{\mathrm{V}}_{\mathrm{i}}$ analysis presented in Table 6 .

According to Cruz et al. (2012), progenies originated from parents with the greatest number of dominant alleles show minimum variance among them $\left(\hat{\mathrm{V}}_{\mathrm{i}}\right)$ and minimum covariance between parent-progeny $\left(\hat{\mathrm{W}}_{\mathrm{i}}\right)$. On the other hand, parents with high number of recessive alleles produce progenies with high variance and covariance. Therefore, the sum of $\hat{W}_{i}+\hat{V} i$ indicated relative concentration of dominant and recessive alleles in the parents.

Number of days to maturation showed similar results to number of days to flowering. Correlations between $\hat{\mathrm{W}}_{\mathrm{I}}+\hat{\mathrm{V}}_{\mathrm{i}}$ and $\bar{Y}$ ii, both in winter (0.7129) and summer (0.8763), show that the dominant alleles contributed to the reduction of the plant's maturation time (Table 5). In the winter, parents TMG123RR and MSOY9144RR showed greater concentration of dominant genes while the parent RSF6563IPRO showed greater concentration of recessive alleles, and the others showed bi-directional dominance deviations (Figure 2C). On the other hand, during summer, parents MSOY6101, RSF6563IPRO, TMG123RR and SYN9078RR showed greater concentrations of dominant alleles and the parent MSOY9144RR showed greater concentration of recessive alleles.

In regards to grain yield, the (r) correlation of -0.5645 and -0.5747 for winter and summer, respectively, shows that dominant genes act to increase character expression.; however, not in an exclusive way (Table 5). Parents MSOY6101, TMG123RR, SYN9078RR, TMG801 and MSOY9144RR showed the greatest number of dominant 
Table 6. Values for the sum of the covariance between parents' means and means for the $r$-th line and the variance between means for the $r$-th line $\left(\hat{\mathrm{W}}_{\mathrm{i}}+\hat{\mathrm{V}}_{\mathrm{i}}\right)$ and means for the days to flowering, days to maturation and yield per plant characters obtained through the Hayman methodology(1954). The study used six soybean parents crossed in a complete diallel scheme and assessed with their F's, in winter and summer.

\begin{tabular}{|c|c|c|c|c|c|c|}
\hline \multirow{3}{*}{ Parent } & \multicolumn{6}{|c|}{$\widehat{W}_{i}+\widehat{V}_{i}$} \\
\hline & \multicolumn{2}{|c|}{ Days to flowering } & \multicolumn{2}{|c|}{ Days to maturation } & \multicolumn{2}{|c|}{ Yield (g'plant) } \\
\hline & Summer & Summer & Winter & Summer & Winter & Summer \\
\hline \multirow{2}{*}{ MSOY6101 } & 3.97 & 22.20 & 4.21 & 19.89 & \multirow{2}{*}{$4.97(8.22)$} & 13.74 \\
\hline & $(59.40)^{]}$ & $(41.40)$ & $(118.20)$ & $(102.20)$ & & $(18.70)$ \\
\hline \multirow{2}{*}{ RSF6563IPRO } & 12.50 & 25.17 & 6.66 & 8.61 & \multirow{2}{*}{$10.51(5.27)$} & 15.75 \\
\hline & $(52.17)$ & $(37.30)$ & $(120.40)$ & $(107.50)$ & & $(16.10)$ \\
\hline \multirow{2}{*}{ TMG123RR } & 12.07 & 35.56 & 0.992 & -0.306 & \multirow{2}{*}{$5.50(11.53)$} & 6.40 \\
\hline & $(59.33)$ & $(45.30)$ & $(118.00)$ & $(107.00)$ & & $(25.00)$ \\
\hline \multirow{2}{*}{ SYN9078RR } & 14.98 & 16.65 & 2.62 & 14.49 & 0.9502 & 5.35 \\
\hline & $(51.83)$ & $(42.70)$ & $(118.00)$ & $(107.80)$ & $(8.57)$ & $(20.60)$ \\
\hline \multirow{2}{*}{ TMG801 } & 13.37 & 98.16 & 5.17 & 83.18 & \multirow{2}{*}{$2.78(10.22)$} & 25.30 \\
\hline & $(61.67)$ & $(56.00)$ & $(121.17)$ & $(110.00)$ & & $(19.30)$ \\
\hline \multirow{2}{*}{ MSOY9144RR } & 24.39 & 103.05 & 2.35 & 133.32 & \multirow{2}{*}{$4.11(11.75)$} & 20.71 \\
\hline & (58.83) & $(58.00)$ & $(119.50)$ & $(127.70)$ & & (18.40) \\
\hline
\end{tabular}

${ }^{1}$ Values within parentheses refer to the phenotypic mean.

alleles in winter and only the TMG123RR and SYN9078RR in summer (Figures 2E and 2F), being the most favorable for superior lineages. Parent RSF6563IPRO in winter, and TMG801 and MSOY9144RR in summer showed the greatest concentrations of recessive alleles.

According to the predicted selection theoretical limits, the parent with maximum dominant homozygosis for number of days to flowering must present $\hat{\mathrm{W}}_{\mathrm{i}}+\hat{\mathrm{V}}_{\mathrm{i}}\left(=\hat{\mathrm{W}}_{\mathrm{D}}+\hat{\mathrm{V}}_{\mathrm{D}}\right)$ equal to -0.2372 in winter and 10.80 in summer. Parents MSOY6101 $\left(\hat{\mathrm{W}}_{\mathrm{i}}+\hat{\mathrm{V}}_{\mathrm{i}}=3.97\right)$ and SYN9078RR $\left(\hat{\mathrm{W}}_{\mathrm{i}}+\hat{\mathrm{V}}_{\mathrm{i}}=16.65\right)$, in summer and winter, respectively, with the lowest values for $\hat{\mathrm{W}}_{\mathrm{i}}+\hat{\mathrm{V}}_{\mathrm{i}}$, are still distant from the predicted values (Tables 5 and 6). Reduction of this character may be reached with greater concentration of dominant alleles and the shortest expected vegetative period $\left(\bar{Y}_{\mathrm{D}}\right)$ is 58.01 and 38.85 in winter and summer, respectively.

For number of days to maturation, the parent with maximum dominant homozygosis should show $\hat{W}_{D}+\hat{V}_{D}=$ 0.3695 in winter and $\hat{W}_{D}+\hat{V}_{D}=7.27$ in summer. In this case, parents closer to the predicted values areTMG123RR and RSF6563IPRO. Thus, the shortest emergence period to maturation, in winter and summer, is expected to be 117.67 and 105.17, respectively. As for grain yield, it is expected that the parent with the maximum concentration of dominant alleles show a $\hat{W}_{i}+\hat{V}_{i}$ sum equal to 0.7914 and -1.62 , in winter and summer, respectively. Considering that parents SYN9078RR, in summer; SYN9078RR and TMG123RR, in winter, were the closest, they are also most certainly to increase this characteristic.

\section{$F_{2}$ evaluation results}

Table 7 shows the results from the sufficiency test of the additive-dominant model for the diallelic analysis, based on the parents' assessment and generation $\mathrm{F}_{2}$. It also shows that there was regression coefficient significance only for grain yield per plant $(\mathrm{P}<0.0149)$.

However, after the axles rotation at $45^{\circ}$, the hypothesis Ho:b'o=0 was rejected, based on a new test. As discussed in the previous results for the diallel with parents and $\mathrm{F}_{1}$ 's, errors in the additive model's assumptions suggest the 
presence of apistasis in character control and, since segregating populations were evaluated, the occurrence of a factorial connection must be considered.

Table 8 shows the genetic parameters estimated for the studied. Significance of the genetic compounds associated with the additive $(\hat{\mathrm{D}})$ and non-additive $\left(\hat{\mathrm{H}}_{1}\right.$ and $\left.\hat{\mathrm{H}}_{2}\right)$ genic effects was only observed for number of days to flowering and number of days to maturation, evidencing that both act in the genetic control of these characters. In regards to grain yield, the dominance effects $\left(\hat{\mathrm{H}}_{1}\right.$ and $\left.\hat{\mathrm{h}}^{2}\right)$ were significant $(\mathrm{P}<0.05)$, thus these effects were more important in character determination. The negative and of high magnitude estimates $\hat{\mathrm{D}}-\hat{\mathrm{H}}_{1}$ also reinforce the presence of dominance genic effects, especially the additive, for all the variables studied.

For all characters, there was overdominance between genes that control them, thus, these results differ from the predominance found in the analysis with the F's (Table 9 and Figure 3). Another important aspect is that the alleles distribution between parents $\left(\hat{\mathrm{H}}_{2} / 4 \hat{\mathrm{H}}_{1}\right)$ were close to 0.25 for the three characters, confirming their symmetric distribution. Moreover, symmetry values estimated for days to flowering, based on the parents and $\mathrm{F}_{2}$ generations, were close to those estimated from the parents and F1's.

Table 7. Sufficiency test of the additive-dominant model based on the linear regression analysis of $\hat{W}_{I}$ in $\hat{V}_{i}$ for the days to flowering, days to maturation and grain yield per plant characters, in a diallelic cross of six soybean parents assessed with the $\mathrm{F}_{2}$, according to the methodology proposed by Hayman (1954).

\begin{tabular}{lccc}
\hline \multirow{2}{*}{ Character } & \multicolumn{3}{c}{ Regression $\left(\widehat{\mathrm{W}}_{\mathrm{i}}=\hat{\mathrm{a}}+\hat{\mathrm{b}} \widehat{\mathrm{V}}_{\mathrm{i}}\right)$} \\
\cline { 2 - 4 } & $\mathrm{b} \pm$ Variance & $\mathrm{t}\left(\mathrm{H}_{0}: \mathrm{b}_{1}=1\right)$ & $\mathrm{F}=\mathrm{t}^{2}\left(\mathrm{H}_{0}: \mathrm{b}^{\prime}{ }_{0}=0\right)^{1}$ \\
\hline Days to flowering & $0.9129 \pm 0.1288$ & $-0.2424^{\mathrm{ns}}$ & $0.2362^{\text {ns }}$ \\
Days to maturation & $0.6535 \pm 0.0780$ & $-1.2404^{\mathrm{ns}}$ & $0.2179^{\text {ns }}$ \\
Yield (g/plant) & $-0.3538 \pm 0.1039$ & $-4.1994^{*}$ & $0.5070^{\text {ns }}$ \\
\hline
\end{tabular}

${ }^{1}$ Test $\mathrm{F}$, with mean values of $\hat{\mathrm{W}}_{\mathrm{I}}$ and $\hat{\mathrm{V}} \mathrm{i}$, weighed with axes rotation at $45^{\circ} .{ }^{\text {ns }}$ non -significant; *significant at $1 \%$ of probability, by the $\mathrm{F}$ test and by the $\mathrm{t}$ test, $\mathrm{b}=$ regression coefficient.

Table 8. Estimators of the genetic and environmental compounds ( \pm Standard Deviation) for the days to flowering, days to maturation and grain yield per plant characters obtained through the Hayman's methodology (1954), for six soybean parents crossed under a complete diallel scheme and evaluated with $\mathrm{F}_{2}$.

\section{Compound}

\section{Characters}

\begin{tabular}{cccc}
\cline { 2 - 4 }$\widehat{\mathrm{D}}$ & Days to flowering & Days to maturation & Yield (g/plant) \\
\cline { 2 - 4 }$\widehat{\mathrm{H}}_{1}$ & $53.55 \pm 8.51^{*}$ & $\mathbf{8 2 . 6 7 \pm 2 1 . 1 2 ^ { * }}$ & $8.87 \pm 33.64$ \\
$\overline{\mathrm{H}}_{2}$ & $260.36 \pm 35.29^{*}$ & $549.99 \pm 87.54^{*}$ & $651.42 \pm 139.47^{*}$ \\
$\widehat{\mathrm{h}}^{2}$ & $227.96 \pm 77.22^{*}$ & $501.16 \pm 191.55^{*}$ & $565.34 \pm 305.19$ \\
$\overline{\mathrm{F}}$ & $11.07 \pm 21.22$ & $50.65 \pm 52.64$ & $315.51 \pm 83.86^{*}$ \\
$\widehat{\mathrm{D}}-\widehat{\mathrm{H}}_{1}$ & $55.61 \pm 39.86$ & $37.84 \pm 98.89$ & $38.99 \pm 157.55$ \\
$\varepsilon$ & $-208.81 \pm 18.97^{*}$ & $-467.32 \pm 47.07^{*}$ & $-642.55 \pm 74.99^{*}$ \\
& $0.7949 \pm 3.21$ & $1.91 \pm 7.98$ & $21.01 \pm 12.72$
\end{tabular}

$\hat{\mathrm{D}}=$ variance compound due to additive effects; $\hat{\mathrm{H}}_{1}=$ variance compound due to non-additive genic effects; $\hat{\mathrm{H}}_{2}=$ genetic variance compound of nonadditive genic effects corrected by the genic distribution; $h_{A}^{2}$, quadratic compound determined by the mean difference between hybrids and parents; $\mathrm{F}=$ genetic compound of the covariance between additive and non-additive genic effects; $\hat{\mathrm{D}}-\hat{\mathrm{H}}_{1}=$ compound that expresses the difference between additive and dominant genic effects; $\mathrm{e}$, Environmental variance compound. Values for $\mathrm{t}$ obtained by the effect estimate divided by its respective standard deviation (Singh and Chaudhary 1979). ns = non-significant. ${ }^{*}=$ significant (values above 1.96 ) at $5 \%$ of probability. 
Table 9. Genetic and non-genetic parameters estimates for days to flowering, days to maturation and grain yield characters per plant, obtained through the Hayman methodology (1954), for six soybean parents, crossed in a complete diallel scheme, and evaluated with the $\mathrm{F}_{2}$ generation.

\begin{tabular}{cccc}
\hline \multirow{2}{*}{ Parameters } & \multicolumn{3}{c}{ Character } \\
\cline { 2 - 4 } & Days to flowering & Days to maturation & Yield (g/plant) \\
\hline$\left(\widehat{\mathrm{H}}_{1} / \widehat{\mathrm{D}}\right)^{0,5}$ & 1.1025 & 1.2897 & 4.2849 \\
$\widehat{\mathrm{H}}_{2} / 4 \widehat{\mathrm{H}}_{1}$ & 0.2189 & 0.2278 & 0.2170 \\
$\mathrm{~K}_{\mathrm{D}} / \mathrm{K}_{\mathrm{R}}$ & 1.6160 & 1.1947 & 1.6901 \\
$\widehat{\mathrm{h}}^{2} / \widehat{\mathrm{H}}_{2}$ & 0.0486 & 0.1011 & 0.5581 \\
$\mathrm{~h}_{\mathrm{R}}^{2}$ & 0.5696 & 0.3958 & 0.0375 \\
$\mathrm{~h}_{\mathrm{A}}^{2}$ & 0.9891 & 0.9890 & 0.8896 \\
\hline
\end{tabular}

$\left(\hat{\mathrm{H}}_{1} / \hat{\mathrm{D}}\right)^{0,5}=$ average degree of dominance; $\hat{\mathrm{H}}_{2} /\left(4 \hat{\mathrm{H}}_{1}\right)=$ distribution of alleles among parents (symmetry); $\mathrm{KD} / \mathrm{KR}=$ average relation for number of dominant and recessive genes; $h_{A}^{2} \hat{H}_{2}=$ number of genes with dominance; $\hat{h}_{R}=$ restricted-sense determination coefficient; and $h_{A}^{2}=$ broad-sense determination coefficients.

The relationship between dominant/recessive alleles $\left(\mathrm{K}_{\mathrm{D}} / \mathrm{K}_{\mathrm{R}}\right)$ and the estimate for number of genes or genic blocks with dominance $\left(h_{A}^{2} / \hat{H}_{2}\right)$ were also similar to those obtained with the parents and $F_{1}$ 's analysis (Tables 4 and 9). Results show the predominance of dominant alleles and that one gene or genic block acts in the control of the characters under study.

Broad-sense determination coefficients $\left(\mathrm{h}_{\AA}^{2}\right)$, for all characters were higher to the estimated for $\mathrm{F}_{1}$, confirming the almost total phenotypical variability as being of genotypic nature. Results also showed that $56.96 \%$ and $39.58 \%$ of the variability for number of days to flowering and to maturation, respectively, is the function of additive genic effects (Table 9). In regards to grain yield, the restricted-sense determination coefficient was lower than that observed for F1's, although it is within the expected for quantitative characters and the evaluated generation.

The correlation between parent mean values $\left(\bar{Y}_{\text {ii }}\right)$ and the covariance sum between parent means and the means for the $r$-th line, and the variance between the means for the $r$-th line $\left(\hat{\mathrm{W}}_{1}+\hat{\mathrm{V}}_{\mathrm{i}}\right)$ were positive and of high magnitude for number of days to flowering (0.9767) and days to maturation (0.9515), and negative for grain yield (-0.6394).

As in the analysis with $\mathrm{F}_{1}$, it allows us to infer that the dominant genes contributed to the plants' flowering and maturation time reduction (Table 10). Parents MSOY6101 and RSF6563IPRO contributed the most for the plants' early flowering, and the same parents, plus the parent SYN9078RR, contributed the most to the plants' maturation time reduction. With greater concentration of recessive alleles, parent MSOY9144RR contributed the most to delay flowering and maturation delay (Figure 3).
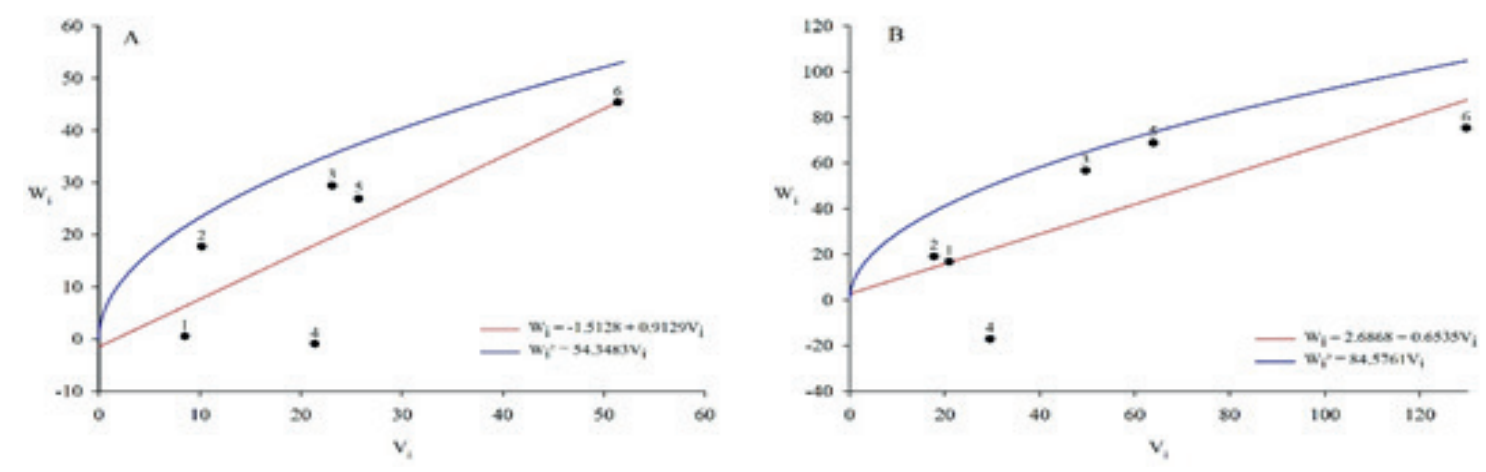

$\begin{array}{ll}\text { 1- MSOY6101 } & \text { 4- SYN9078RR } \\ \text { 2- RSF6563IPRO } & \text { 5-TMG801 } \\ \text { 3- TMG123RR } & \text { 6- MSOY9144RR }\end{array}$

Figure 3. Regressions of $\hat{\mathrm{W}}_{\mathrm{i}}$ in $\hat{\mathrm{V}}_{\mathrm{i}}$ for the number of days to flowering (A) and number of days to maturation (B) characters for soybean parents evaluated with their $\mathrm{F}_{2}$ progenies, in Viçosa, MG, Brazil, 2016. 
Table 10. Estimates for the correlation between parent mean values $\left(\hat{Y}_{\text {iii }}\right)$ and the sum of the covariance between parent means and means for the $r$-th line, and the variance between means of the $r$-th line $\left(\hat{W}_{I+} \hat{V}_{i}\right)$, expected values for the coordinates $\left(\hat{\mathrm{W}}_{\mathrm{R}} ; \hat{\mathrm{V}}_{\mathrm{R}}\right)$ and $\left(\hat{\mathrm{W}}_{\mathrm{D}} ; \hat{\mathrm{V}}_{\mathrm{D}}\right)$ and predicted value for the parent with the maximum concentration of dominant alleles $\left(\bar{Y}_{R} ; \hat{Y}_{i D}\right)$. Estimates were based on six soybean parents assessed with the $\mathrm{F}_{2}$ generation, in a complete diallelic scheme.

\begin{tabular}{lccccc}
\hline & \multicolumn{5}{c}{ Genetic parameters } \\
\cline { 2 - 6 } Character & $\mathrm{r}\left(\mathrm{W}_{\mathrm{i}}+\mathrm{V}_{\mathrm{i}}\right.$ & $\left(\mathrm{W}_{\mathrm{R}} ; \mathrm{V}_{\mathrm{R}}\right)$ & $\left(\mathrm{W}_{\mathrm{D}} ; \mathrm{V}_{\mathrm{D}}\right)$ & Prediction equation & Limit $\left(\mathrm{Y}_{\mathrm{R} ;} \mathrm{Y}_{\mathrm{D}}\right)$ \\
& $\left.\mathrm{Y}_{\mathrm{ii}}\right)$ & & & & \\
\hline \multirow{2}{*}{$\mathrm{DF}^{1}$} & 0.9767 & $(61.0038 ;$ & $(-1.4762 ;$ & $\mathrm{Yr}_{\mathrm{r}}=40.216159+$ & \\
& & $68.4745)$ & $0.0401)$ & $0.228618(\mathrm{Wi}+\mathrm{Vi})$ & $(69.8172 ; 39.8878)$ \\
& & $(126.6777 ;$ & $(2.7450 ;$ & $\mathrm{Yr}_{\mathrm{r}}=117.3001+$ & $(155.0228 ;$ \\
$\mathrm{DM}^{2}$ & 0.9515 & $189.7371)$ & $0.0891)$ & $0.119219(\mathrm{Wi}+\mathrm{Vi})$ & $117.6380)$ \\
& & & & & \\
\hline
\end{tabular}

${ }^{1} \mathrm{DF}=$ days to flowering; and $2 \mathrm{DM}=$ days to maturation.

The parent with the maximum dominant homozygosis must show $\hat{W}_{D^{+}} \hat{V}$ D equal to -1.48 for days to flowering and 2.83 for days to maturation, whose closest parents are MSOY6101 and SYN9078RR, respectively (Table 11). So, the theoretical limits for selection were 38.89 to 69.81 for number of days to flowering and 117.64 to 155.02 for number of days to maturation (Table 10). When compared to the results obtained from the parents analysis and their $F_{1}$ 's, the lower number of days to flowering was similar to that obtained in the summer and to days to maturation very close to that estimated for the winter. The superior limits were not so close; however, they remained within the parametric space.

Table 11. Values for the sum of the covariance between parent means and means for the $r$-th line, and of the variance between means for the $r$-th line $\left(\hat{\mathrm{W}}_{\mathrm{i}}+\hat{\mathrm{V}}_{\mathrm{i}}\right)$ and means for days to flowering, days to maturation and plant yield. Data obtained through the methodology proposed by Hayman (1954), for six soybean parents, crossed under a complete diallel scheme, and evaluated with generation $\mathrm{F}_{2}$.

\section{Character}

\begin{tabular}{lcccccc}
\multirow{2}{*}{ Parent } & \multicolumn{2}{c}{ Days to flowering } & \multicolumn{2}{c}{ Days to maturation } & \multicolumn{2}{c}{ Yield (g/plant) } \\
\cline { 2 - 7 } & $\mathrm{W}_{\mathrm{i}}+\mathrm{V}_{\mathrm{i}}$ & Mean & $\mathrm{W}_{\mathrm{i}}+\mathrm{V}_{\mathrm{i}}$ & $\mathrm{M}$ Mean & $\mathrm{W}_{\mathrm{i}}+\mathrm{V}_{\mathrm{i}}$ & Mean \\
\hline MSOY6101 & 9.02 & 44.68 & 37.65 & 121.11 & 59.92 & 57.36 \\
RSF6563IPRO & 27.91 & 44.15 & 36.76 & 121.34 & 72.22 & 56.13 \\
TMG123RR & 52.50 & 52.19 & 106.36 & 129.69 & 19.28 & 55.08 \\
SYN9078RR & 20.44 & 44.53 & 12.39 & 121.56 & 30.21 & 59.85 \\
TMG801 & 52.61 & 51.93 & 132.71 & 128.48 & 56.95 & 58.61 \\
MSOY9144RR & 96.71 & 63.07 & 205.16 & 144.93 & 92.16 & 44.68 \\
\hline
\end{tabular}

Alleles of the ten loci described until now, together with the photoperiod (Cober et al., 1996) and temperature (Cober et al., 2001), regulate flowering and maturity time in soybean. For being short-day plants, under non-inductive conditions, longer days $(>14 \mathrm{~h})$ and high temperatures $\left(25\right.$ to $30{ }^{\circ} \mathrm{C}$, the dominant alleles delay flowering, with the exception of the E6 locus. Lower temperatures minimize the delay effect on the $\mathrm{E}$ alleles under non-inductive photoperiods (Cober et al., 2001). 
This study shows results obtained from soybean developed under photoperiodic conditions, varying from 10 hours and 54 minutes to 13 hours and 13 minutes in the summer, characterizing the non-inductive photoperiod. Therefore, the results differ from those obtained by Bernard (1971), Buzzell (1971), Buzzell and Voldeng (1980), and McBlain and Bernard (1987), who attested that dominant alleles are responsible for controlling late cycle under long-days conditions. However, they corroborate with the results obtained by Hartwig and Kiihl (1979), Ray et al. (1995), Bonato and Vello (1999b) and Zhao et al. (2016) for the E9/e9 locus, under photoperiodic conditions close to 14 hours.

In regards to grain yield, the fact that the character is quantitative does not impede an analysis via the Hayman methodology (1954), providing that the species is diplod, as in the case of soybean, and meets the model's assumptions. However, the presence of epistatic interactions in the genetic control of yield becomes a disturbing element in the additive-dominant model adjustment. Thus, it is necessary the realization of new studies to determine the efficiency of the methodology used to study characters of this nature. Another option is the transformation of the data scale and the realization of a new model sufficiency test.

\section{CONCLUSIONS}

The effects of additive and dominance genetics were important for the genetic control of number of days to flowering and maturation and grain yield per plant. Number of days to flowering and maturation, and grain yield for the $F_{1}$ generations, in the winter and summer, and $\mathrm{F}_{2}$ in the summer, are determined by dominant alleles. There was an important partial dominance in all characters in the $\mathrm{F}_{\mathrm{I}}$ generation and overdominance in the $\mathrm{F}_{2}$ generation.

Parents MSOY6101 and RSF6563IPRO showed greater concentration of alleles favorable to flowering and maturation time reduction, and parents TMG123RR and SYN9078RR to grain yield. Parents TMG801 and MSOY9144RR.contributed the most for the delay of the $\mathrm{F}_{2}$ generation cycle.

\section{REFERENCES}

Alvares CA, Stape JL, Sentelhas PC, De Moraes G, Leonardo J and Sparovek G (2013) Köppen's climate classification map for Brazil. Meteorologische Zeitschrift 22: 711-728.

Barona MAA, Colombari Filho JM, Santos VS and Geraldi IO (2012) Epistatic effects on grain yield of soybean [Glycine max (L.) Merrill]. Crop Breeding Applied and Biotechnology 12: 231-236.

Barona MAA, Colombari Filho JM and Geraldi IO (2009) Epistasia para a produtividade de grãos em soja. Bragantia 68: 313-318.

Bernard RL (1971) Two major genes for time of flowering and maturity in soybeans. Crop Science 11: 242-244.

Bonato ER and Vello NA (1999a) E6, a dominant gene conditioning early flowering and maturity in soybeans. Genetics and Molecular Biology 22: 229-232.

Bonato ER and Vello NA (1999b) Aspectos genéticos do tempo para o florescimento em variantes naturais de soja. Pesquisa Agropecuária Brasileira 34: 989-993.

Buzzell RI (1971) Inheritance of a soybean flowering response to fluorescente-daylenth conditions. Canadian Journal of Genetic Cytology 13: 703-707.

Buzzell RI and Voldeng HD (1980) Inheritance of insensitivity to long day-lenth. Soybean Genetics Newslatter 7:26-29.

Cober ER, Molnar SJ, Charette M and Voldeng HD (2010) A new locus for early maturity in soybean. Crop Science 50: 524-527.

Cober ER, Tanner JW and Voldeng H (1996) Genetic control of photoperiod response in early-maturing, near isogenic soybean lines. Crop Science 36, 601-605.

Cober ER and Voldeng HD (2001) A new soybean maturity and photoperiod sensitivity locus linked to Er and T. Crop Science 41: 698-701. 
Cruz CD (2013) GENES - a software package for analysis in experimental statistics and quantitative genetics. Acta Scientiarum Agronomy 35: 271-276.

Cruz CD, Regazzi AJ and Carneiro PCS (2012) Modelos biométricos aplicados ao melhoramento genético4 ${ }^{\text {th }}$ ed. Editora UFV, Viçosa, 514p, v.1.

Fehr WR and Caviness CE (1977) Stages on soybean development. Special Report, 80. Iowa State University/Cooperative Extention Service, Ames, 11p.

Hartwig EE and Kiihl RAS (1979) Identification and utilization of a delayed flowering character in soybeans for short-day conditions. Field Crops Research 2: 45-51.

Hayman BI (1954) The theory and analysis of diallel crosses. Genetics 39: 789-809.

Jinks JL (1956) The F2 and backcross generations from a set of diallel crosses. Heredity 10: 1-30.

Kong F, Nan H, Cao D, Li Y, Wu F, Wang J, Lu S, Yuan X, Cober ER, Abe J and Liu B (2014) A new dominant gene E9 conditions early flowering and maturity in soybean. Crop Science 54: 2529-2535.

Mc Blain BA and Bernard RL (1987) A new gene affecting the time of maturity in soybean. Journal of Heredity 78: $160-162$.

Novais RF, Neves JCL and Barros NF (1991) Ensaio em ambiente protegido. In: Oliveira AJ, Garrido WE, Araujo JD and Lourenço S (coords.) Métodos de pesquisa em fertilidade do solo. EMBRAPA, Brasília, 392p.

Ray JD, Hinson K, Mankono EB and Malo FM (1995) Genetic control of a long-juvenile trait in soybean. Crop Science 35: 1001-1006.

Singh RK and Chaudhary BD (1979) Biometrical methods in quantitative genetic analysis. Kalyani Publishers, New Delhi, 304p.

Toledo JFF and Kiihl RAS (1982) Análise do modelo genético envolvido no controle de dias para o florescimento em soja. Pesquisa Agropecuária Brasileira 17: 623-631.

Tsubokura Y, Watanabe S, Xia Z, Kanamori H, Yamagata H, Kaga A, Katayose Y, Abe J Ishimoto M and Harada K (2014) Natural variation in the genes responsible for maturity loci E1, E2, E3 and E4 in soybean. Annals of Botany 113: 429-441.

Xu M, Xu Z, Liu B, Kong F, Tsubokura Y, Watanabe S, Xia Z, Harada K, Kanazawa A, Yamada T and Abe J (2013) Genetic variation in four maturity genes affects photoperiod insensitivity and PHYA-regulated post-flowering responses of soybean. BMC Plant Biology 13: 1-14.

Yamanaka N, Ninomiya S, Hoshi M, Tsubokura Y, Yano M, Nagamura Y, Sasaki T and Harada K (2001) An informative linkage map of soybean reveals QTLs for flowering time, leaflet morphology and regions of segregation distortion. DNA Research 8: 61-72.

Yang Z, Xin D, Liu C, Jiang H, Han X, Sun Y, Qi Z, Hu Z and Chen Q(2013) Identification of QTLs for seed and pod traits in soybean and analysis for additive effects and epistatic effects of QTLs among multiple environments. Molecular Genetics Genomics 288: 651-667.

Received: November 30, 2016.

Accepted: April 24, 2017.

Published: September 04, 2017. 